\title{
PENGARUH DIVERSITAS JENDER DAN UKURAN DEWAN TERHADAP DIVIDEND PAYOUT
}

\author{
Herni Kurniawati ${ }^{1}$, Fanny Andriani Setiawan ${ }^{2}$ \\ ${ }^{1}$ Jurusan Akuntansi, Universitas Tarumanagara, Jakarta \\ ${ }^{1}$ Email: hernik@fe.untar.ac.id \\ ${ }^{2}$ Jurusan Akuntansi, Universitas Tarumanagara, Jakarta \\ ${ }^{2}$ Email: fannys@fe.untar.ac.id
}

\begin{abstract}
The purpose of this research is to empirically prove how gender diversity and the size of the board have an impact on the dividends paid to investors in manufacturing companies. This research uses a descriptive quantitative approach. This research sample is secondary data from the annual report of manufacturing companies for the 2016 2019 period. The software used in this research is the eviews 10 program. This research provides the following results: (1) that the gender diversity of board members in manufacturing companies does not affect dividend payments; and (2) the size of the board of directors in manufacturing companies does not affect dividend payments/dividend payments in manufacturing companies. The implication of this research is to give advice to companies to recruit more board members to force companies to better protect and prioritize the interests of shareholders through cash disbursement in the form of dividends, so that they will be able to attract investors to invest. Contribute by increasing knowledge related to research on what things encourage dividend payments to investors. These factors include gender diversity and the size of the company's board members.
\end{abstract}

Keywords: Dividend pay-out; Gender diversity; Board size

\begin{abstract}
ABSTRAK
Tujuan riset ini adalah membuktikan secara empiris bagaimana keragaman gender dan ukuran anggota dewan berdampak terhadap dividen yang dibayarkan untuk investor perusahaan manufaktur. Riset ini memakai metode deskriptif pendekatan kuantitatif. Sampel riset ini berupa data sekunder dari laporan tahunan perusahaan manufaktur periode 2016-2019. Perangkat lunak yang digunakan riset ini adalah program eviews 10. Riset ini memberikan hasil: (1) bahwa keragaman gender anggota dewan di perusahaan manufaktur tidak mempengaruhi pembayaran dividen; dan (2) ukuran dewan direksi pada perusahaan manufaktur tidak mempengaruhi pembayaran dividen/pembayaran dividen pada perusahaan manufaktur. Implikasi riset ini yaitu memberikan saran ke perusahaan untuk merekrut banyak anggota dewan untuk memaksa perusahaan lebih melindungi dan mengutamakan kepentingan pemegang saham melalui pencairan kas dalam bentuk deviden, sehingga akan mampu menarik investor untuk berinvestasi. Berkontribusi dengan menambah pengetahuan terkait riset mengenai hal-hal apa saja yang mendorong pembayaran dividen kepada investor. Faktor-faktor tersebut meliputi keragaman gender dan ukuran anggota dewan perusahaan.
\end{abstract}

Kata Kunci: Dividend pay-out; Diversitas Jender; Ukuran Dewan

\section{PENDAHULUAN \\ Latar Belakang}

Pembagian dividen merupakan waktu yang paling ditunggu oleh para pemegang saham untuk menerima haknya, akan tetapi tahun 2020 terjadinya pandemik virus berefek kepada hak dari investor. Tahun 2020 di semua negara baik itu negara maju dan berkembang di dunai mengalami goncangan ekonomi karena virus pandemik Covid-19. Kondisi pandemik tersebut membuat para investor mengalami ketakutan tidak menerima hak mereka yaitu dividen. Namun, Pemerintah Indonesia tidak tinggal diam menghadapi pandemi Covid-19, yaitu dengan memberikan insentif ekonomi yang juga diarahkan ke sektor pasar modal, dengan memberikan penurunan tarif Pajak Penghasilan (PPh) Badan dan pajak dividen (https://www.kominfo.go.id/, 2020). Dengan pemberian stimulus pengurangan pajak dividen, diharapkan perusahaan akan terus memberikan dividen kepada pemegang saham untuk meningkatkan pertumbuhan ekonomi.

Indonesia adalah negara berkembang di benua Asia memiliki ciri-ciri kurang memberikan perlindungan terhadap hak-hak minoritas, besarnya jumlah kepemilikan saham oleh pemerintah, dan juga ketidakpastian pasar sehingga mengakibatkan kebijakan sulit diestimasi mekanisme 
pendugaan pembayaran dividen di negara berkembang (Saeed \& Sameer, 2017). Risiko terbesar yang sering dihadapi manajemen di negara berkembang adalah perubahan ekonomi, aktivitas pesaing, teknologi yang berubah, dan aturan hukum yang berubah (Thornton, 2015). Perubahan ekonomi yang terjadi di Indonesia ditahun 2020 adalah terkena dampak pandemik virus Covid19 dimana perubahan ekonomi memaksa perusahaan menahan laba nya agar tidak diberikan kepada investor dalam bentuk dividen.

Fauziah dan Probohudono (2018) dalam risetnya telah membuktikan perusahaan yang dapat menghasilkan keuntungan besar cenderung menahan keuntungannya, dengan alasan jumlah pengembalian dalam bentuk dividen lebih kecil dibandingkan dengan jumlah jika keuntungan perusahaan di investasikan kembali di periode berikutnya. Hasil riset tersebut konsisten dengan paham agency theory, dimana menurut agency theory bahwa manajer perusahaan memakai sumber daya perusahaan yang memberikan keuntungan bagi dirinya sendiri, dibandingkan menguntungkan investor (Jensen, 1986; Saeed \& Sameer, 2017). Sehingga agency theory menimbulkan masalah keagenan, dan salah satu cara menurunkan masalah keagenan adalah dengan melakukan pembayaran dividen dengan jumlah yang lebih besar kepada investor sehingga dapat mengurangui jumlah uang tunai yang dimiliki manajer. Firth, Gao, Shen, \& Zhang, 2016; Ben-Nasr, 2015). Hal ini menimbulkan tanya mengenai bagaimana anggota dewan dapat dipengaruhi untuk membayar lebih banyak dividen kepada pemegang saham ketika karakter mereka adalah menyimpan surplus kas untuk diinvestasikan. Salah satu cara yang mungkin untuk menjawab pertanyaan ini adalah dengan memasukkan orang dengan karakteristik, latar belakang pendidikan, dan keterlibatan yang berbeda sebagai anggota dewan yang mungkin kompeten untuk mempengaruhi keputusan dewan, termasuk yang berkaitan dengan dividen. Penelitian sebelumnya telah menggali bagaimana berbagai macam karakteristik anggota dewan sebagai ukuran anggota dewan (Van Pelt, 2013), direktur independen (Boumosleh \& Cline, 2015), dualitas CEO (Sawicki, 2009), usia dan keterlibatan menjadi anggota dewan (Custodio \& Metzger, 2014) mempengaruhi kebijakan dividen. Meskipun demikian, relatif sedikit bukti empiris tentang apakah komposisi gender dewan memengaruhi pembayaran dividen.

Riset mengenai keragaman gender yang sudah dibuktikan beberapa peneliti menghasilkan hasil yang berbeda seperti riset yang dibuktikan oleh Tahir et.al. (2020) bahwa anggota dewan perempuan tidak berpengaruh terhadap pembayaran dividen di perusahaan non-keuangan Malaysia. Hasil yang berbeda dibuktikan oleh (Byoun et al., 2016) bahwa anggota dewan perempuan dapat memberikan dampak positif pada pembayaran dividen di perusahaan yang terdaftar di database IRRC. Hasil riset yang sama dibuktikan oleh (Al-Rahahleh, 2017) di sebuah perusahaan keuangan Yordania bahwa semakin banyak anggota dewan perempuan dapat menyebabkan dampak positif pada pembayaran dividen. Sedangkan hasil penelitian dari (Saeed \& Sameer, 2017) membuktikan bahwa keberadaan perempuan dalam anggota dewan memiliki pengaruh negatif terhadap perusahaan-perusahaan di India, China, dan Rusia. Mendukung hasil penelitian Saeed \& Sameer, hasil Duong et al. (2020) yang sampel penelitiannya adalah perusahaan Vietnam, juga membuktikan bahwa lebih dari tiga anggota dewan perempuan dapat menyebabkan dampak negatif pada pembayaran dividen.

Research gap yang terjadi yaitu beberapa hasil riset tidak menghasilkan hasil yang sama/ konsisten mengenai pengaruh keragaman perempuan pada anggota dewan terhadap dividend payout.

\section{Rumusan Masalah}

Berdasarkan penjabaran isu-isu riset diatas, rumusan masalah yang diajukan sebagai berikut:

1. Apakah diversitas jender wanita anggota dewan berpengaruh positif terhadap dividend payout? 
2. Apakah ukuran anggota dewan (board size) berpengaruh positif terhadap dividend payout?

\section{METODE PENELITIAN}

Desain dari riset berupa deskriptif dengan pendekatan kuantitatif karena menggunakan data laporan keuangan perusahaan manufaktur yang diperoleh dari Pojok Bursa FEB Universitas Tarumanagara dan situs web Bursa Efek Indonesia. Riset ini memanfaatkan seluruh perusahaan publik manufaktur tahun 2016-2019 sebagai populasi riset, dengan sampel riset adalah perusahaan public tahun 2016-2019. Sampel riset yang ditentukan menggunaka teknik purposive sampling, karena target sampel harus sesuai dengan kriteria yang ditentukan.

Dibawah ini adalah beberapa kualifikasi dijadikan sampel penelitian, yaitu:

a) Tercatat di BEI secara berkesinambungan dalam periode 2016-2019.

b) Tidak rugi selama periode 2016-2019.

c) Laporan keuangan menggunakan mata uang rupiah (simbol: IDR).

d) Membagikan dividen pada periode 2016-2019.

e) Perusahaan tidak melakukan merger

f) Tidak melakukan IPO pada periode 2016-2019.

g) Tidak mengalami delisting dari BEI pada periode 2016-2019

Dari hasil teknik purposive sampling diperoleh kesimpulan bahwa data penelitian terdiri dari 176 observasi.

Table 1. Operasional Variabel

\begin{tabular}{ll}
\hline \multicolumn{1}{c}{ Variabel } & \multicolumn{1}{c}{ Pengukuran } \\
\hline 1. Dependent & Dividen tunai / Laba Bersih \\
\hline Dividend payout Ratio (Tahir et al., 2020) & \\
\hline 2. Independent & $\begin{array}{l}\text { Jumlah anggota dewan wanita/ Jumlah anggota } \\
\text { dewan }\end{array}$ \\
\hline Diversitas Jender Wanita (Tahir et al., 2020) & Jumlah Anggota Dewan \\
\hline Ukuran dewan (Tahir et al., 2020) & $\begin{array}{l}\text { di proksi kan dengan logaritma dari nilai } \\
\text { kapitalisasi perusahaan. }\end{array}$ \\
\hline 3.Control & $\begin{array}{l}\text { CR = Total Current Assets / Total Current } \\
\text { Siabilities }\end{array}$ \\
\hline Likuiditas & ROE = Net Income / Total Equity \\
\hline Profitabilitas &
\end{tabular}

Model riset yang digunakan yaitu regresi data panel dengan persamaan sebagai berikut:

Information:

$$
\text { DPRt = ait + bJENDit + cBSit + dSIZEit + eCRit + fROEit + eit }
$$

$\begin{array}{ll}\text { DPR } & =\text { Dividend Pay-out Ratio } \\ \text { JEND } & =\text { Wanita } \\ \text { BS } & =\text { Ukuran dewan } \\ \text { SIZE } & =\text { Ukuran perusahaan } \\ \text { CR } & =\text { Likuiditas } \\ \text { ROE } & =\text { Profitabilitas } \\ \text { e } & =\text { error }\end{array}$




\section{HASIL DAN PEMBAHASAN}

Tujuan menganalisis data panel pada riset agar memahami bagaiamana pembiayaan memperngaruhi nilai perusahaan, dengan periode riset tahun 2016-2019. Dibawah ini hasil pengolahan data panel menggunakan model fixed effect yang menghasilkan persaman regresi data panel sebagai berikut:

$\mathrm{DPR}=0,35877009707-0,14591907842 * \mathrm{JEND}+\mathbf{0 , 0 1 4 9 6 5 1 5 0 4 6 6 9} * \mathrm{BS}+\mathbf{2 , 4 3 5 3 2 5 3 0 0 1 6 \mathrm { e } -}$ 07*SIZE + 0,00700629425952*CR - 0,183132296002*ROE

Tabel 2. Hasil Estimasi Model Penelitian

\begin{tabular}{|l|c|c|c|}
\hline \multicolumn{1}{|c|}{ Variabel } & Koefisien & t-statistik & Probabilitas \\
\hline C & 0,325747 & 0,495610 & 0,6210 \\
\hline JEND & $-0,217960$ & $-0,229814$ & 0,8186 \\
\hline BS & 0,018233 & 0,310865 & 0,0564 \\
\hline SIZE & $2.38 \mathrm{E}-07$ & 0,097667 & 0,9224 \\
\hline CR & $-0,003959$ & $-0,217066$ & 0,8285 \\
\hline ROE & 0,033054 & 0,103422 & 0,0178 \\
\hline R-squared & 0,325747 & Mean dependent var & 0,490813 \\
\hline Adjusted R-squared & 0,152988 & S.D. dependent var & 0,625390 \\
\hline F-statistic & 1,658515 & Durbin-Watson stat & 2,118108 \\
\hline Prob (F-statistic) & 0,013421 & & \\
\hline
\end{tabular}

Sumber: Output Eviews 10

Pada tabel hasil estimasi model peneitian di atas dari persamaan regresi data panel bahwa koefisien konstanta sebesar 0,358770. Angka tersebut menggambarkan terdapat variabel sistematis lain yang juga mempengaruhi pembayaran dividen, akan tetapi tidak masuk dalam model. Koefisien dari variabel-variabel tersebut secara konglomerasi bernilai positif. Sebab adanya beberapa variable yang tidak masuk dalam model, angka-angka sistematis tersebut masuk ke dalam konstanta yang menyebabkan koefisien konstanta menjadi positif. Variabelvariabel bebas dalam model riset yang berpengaruh terhadap nilai perusahaan di terangkan sebagai berikut:

\section{H1: Diversitas jender berpengaruh positif terhadap dividend payout}

Berdasarkan hasil uji regresi data panel terbukti memberikan hasil yang berbeda dengan hipotesis yang diajukan yaitu diversitas jender anggota dewan tidak berpengaruh positif terhadap pembayaran dividen kepada pemegang saham perusahaan manufaktur. Hasil riset ini menyokong riset yang telah dibuktikan Tahir et al. (2020) yang membuktikan bahwa anggota dewan perempuan tidak berpengaruh terhadap dividend payout di perusahaan non-keuangan Malaysia. Hasil penelitian yang sama dibuktikan oleh (Saeed \& Sameer, 2017) bahwa diversitas jender pada anggota dewan tidak berpengaruh terhadap dividend payout di perusahaan publik Rusia.

\section{H2: Ukuran dewan berpengaruh positif terhadap pembayaran dividen.}

Berdasarkan hasil uji regresi data panel terbukti menerima $\mathrm{H} 2$ dengan nilai probabilitas kurang dari taraf signifikansi 10\% (0,0564), sehingga dapat dikatakan penelitian ini berpengaruh positif ukuran dewan pada pembayaran dividen. Hasil riset ini menyokong hasil riset (Subramaniam, R., et al., 2011; Uwalomwa et al., 2015) menemukan hubungan positif antara ukuran dewan dan pembayaran dividen. Studi ini menunjukkan bahwa perusahaan dengan ukuran anggota dewan yang besar dan sampel penelitian adalah milik keluarga, perusahaan dituntut untuk bertanggung jawab membayar lebih banyak dividen. 


\section{Variabel Kontrol}

Hasil regresi data panel antara variabel kontrol dan pembayaran dividen memberikan hasil yang berbeda. Variabel kontrol yang terdiri dari ukuran perusahaan (size) dan likuiditas (rasio lancar) tidak berpengaruh terhadap pembayaran dividen, sedangkan profitabilitas (ROE) berpengaruh positif terhadap pembayaran dividen. Variabel kontrol ukuran perusahaan (size) tidak berpengaruh positif terhadap pembayaran dividen karena calon investor memahami bahwa ukuran perusahaan tidak dapat dijadikan sebagai jaminan untuk membayar kewajibannya kepada investor berupa dividen setiap tahunnya, karena keuntungan yang diperoleh dalam tahun sebelumnya dapat digunakan kembali untuk menambah modal usaha (dikenal dengan laba ditahan). Sehingga dapat mengurangi besarnya leverage (utang) dan bunga yang biasa digunakan untuk menambah modal. Hal ini mendukung hasil penelitian Nuringsih (2005) dimana perusahaan dengan aset besar jika melakukan ekspansi akan dibiayai dengan penambahan utang atau saham. Karena perusahaan dalam menentukan kebijakan dividen tidak terlalu mempertimbangkan total asetnya. Selain itu, perusahaan dengan total aset yang kecil dapat memberikan dividen dalam rasio yang tinggi. Sehingga ukuran perusahaan tidak berpengaruh besar terhadap rasio pembayaran dividen (Sinabutar \& Anggoro, 2015).

Variabel kontrol likuiditas dalam riset terbukti tidak berpengaruh terhadap pembayaran dividen pada perusahaan manufaktur periode 2016-2019. Alasannya karena current ratio hanya mengukur kapabilitas perusahaan untuk melunasi utang-utang jangka pendeknya (Sinabutar \& Anggoro, 2015); (Akbar, 2020). Variabel kontrol profitabilitas yang diukur dengan Return on Equity (ROE) menyampaikan hasil yang berpengaruh positif terhadap pembayaran dividen perusahaan manufaktur. Hasil ini sesuai dengan hasil penelitian Madyoningrum (2019); Ara'Afi (2020) yang mengatakan bahwa rasio profitabilitas adalah rasio yang mengukur seberapa besar keuntungan yang bisa diperoleh perusahaan sehingga jika perusahaan dapat meningkatkan profitabilitasnya maka akan memberikan rasa aman bagi investor untuk menerima dividen secara rutin setiap hari. tahun.

\section{KESIMPULAN DAN SARAN}

Riset ini menghasilkan kesimpulan yaitu: Pertama, Diversitas jender anggota dewan tidak berpengaruh positif terhadap dividend payout bagi pemegang saham perusahaan manufaktur. Pasalnya, proporsi persentase anggota dewan perempuan di perusahaan manufaktur rata-rata kurang dari $30 \%$ sehingga tidak berdampak pada keputusan pembayaran dividen bagi investor. Kedua, ukuran Dewan berpengaruh positif terhadap pembayaran dividen. Alasannya karena riset ini menunjukkan bahwa perusahaan dengan ukuran anggota dewan yang besar dan sampel penelitian adalah milik keluarga, perusahaan dituntut untuk bertanggung jawab membayar lebih banyak dividen. Ketiga, variabel kontrol ukuran perusahaan tidak berpengaruh positif terhadap pembayaran dividen karena calon investor memahami bahwa ukuran perusahaan tidak dapat dijadikan sebagai jaminan untuk membayar kewajibannya kepada investor berupa dividen setiap tahun, karena keuntungan yang diperoleh dalam tahun sebelumnya dapat digunakan kembali untuk menambah modal usaha (dikenal dengan laba ditahan). Sehingga dapat mengurangi besarnya leverage (utang) dan bunga yang biasa digunakan untuk menambah modal. Keempat, variabel kontrol likuiditas dalam penelitian terbukti tidak berpengaruh terhadap pembayaran dividen pada perusahaan manufaktur periode 2016-2019. Alasannya, rasio lancar hanya untuk mengukur kemampuan perusahaan dalam membayar utang jangka pendeknya. Dan kelima, variabel kontrol Profitabilitas dengan proksi Return on Equity (ROE) memberikan hasil yang berdampak positif atas pembayaran dividen pada perusahaan manufaktur. Profitabilitas adalah rasio yang menghitung berapa besarnya laba yang dapat diperoleh perusahaan, sehingga apabila perusahaan dapat meningkatkan profitabilitasnya maka akan memberikan rasa aman bagi investor untuk menerima dividen secara rutin setiap tahunnya. 
Implikasi dari riset yaitu menyampaikan masukan untuk manajemen perusahaan sebaiknya merekrut banyak anggota dewan untuk memaksa perusahaan lebih melindungi dan mengutamakan kepentingan pemegang saham melalui pencairan kas dalam bentuk dividen, sehingga akan dapat menarik investor untuk berinvestasi. Keterbatasan dari riset ini hanya melibatkan perusahaan manufaktur sebagai sampel penelitian karena perusahaan tersebut memiliki proporsi terbesar dari perusahaan yang terdaftar di Bursa Efek Indonesia yang pada akhirnya hasil riset tidak bias.

Saran yang diberikan berdasarkan hasil riset untuk riset selanjutnya dapat mengambil sampel penelitian non manufaktur seperti perbankan dan keuangan. Peneliti selanjutnya dapat mengganti menambah variabel kontrol yang dapat mempengaruhi dividends payout/ pembayaran dividen

\section{Ucapan Terima Kasih (Acknowledgement)}

Lembaga Penelitian dan Pengabdian kepada Masyarakat (LPPM) Universitas Tarumanagara yang telah memberikan kontribusi dana kegiatan Penelitian kepada tim pelaksana yang terlibat dalam kegiatan Penelitian sehingga kegiatan ini dapat berjalan lancar.

\section{REFERENSI}

Adamu, Adamu Idris, Ishak, Rokiah, \& Hasan, Nor Laili. (2017). Is there relationship between board structures and dividend policy: Evidence from Nigeria. Journal of Advances Research in Business and Management Studies, 9(1), 10-20. Retrieved from: http://www.akademiabaru.com/submit/index.php/arbms/article/view/1274

Akbar, Firlana \& Irham Fahmi. (2020). Pengaruh Ukuran Perusahaan, Profitabilitas, dan Likuiditas Terhadap Kebijakan Dividen dan Nilai Perusahaan Pada Perusahan Manufkatur yang terdaftar di BEI. Jurnal Ilmiah Mahasiswa Ekonomi Manajemen, 5(1), 62-81. Retrieved from: http://jim.unsyiah.ac.id/ekm

Al-Rahahleh, Ayat S. (2017). Corporate Governance Quality, Board Gender Diversity and Corporate Dividend Policy: Evidence from Jordan. Australasian Accounting, Business and Finance Journal, 11(2), 86-104. DOI: 10.14453/aabfj.v11i2.6

Ararat, Melsa, Aksu, Mine H., and Cetin, Ayse Tansel. (2010). The Impact of Board Diversity on Boards' Monitoring Intensity and Firm Performance: Evidence from the Istanbul Stock Exchange. DOI: 10.2139/ssrn.1572283

Ben-Nasr, Hamdi. (2015). Government ownership and dividend policy: Evidence from newly privatized firms. Journal of Business Finance \& Accounting, 42(5), 665-704. DOI: $10.1111 /$ jbfa. 12115

Bernile, Gennaro., Bhagwat, Vineet, \& Yonker, Scott. (2018). Board diversity, firm risk, and corporate policies. Journal of Financial Economics, 127(3), 588-612. DOI: 10.1016/j.jfineco.2017.12.009

Betz, M., O'Connell, L. \& Shepard, J.M. (1989). Gender differences in proclivity for unethical Behavior. Journal of Business Ethics, 8(5), 321-324. DOI: 10.1007/BF00381722

Boumosleh, A., \& Cline, Brandon. N. (2015). Outside director stock options and dividend policy. Journal of Financial Services Research, 47(3), 381-410. DOI: 10.1007/s10693-013-0174-2

Byoun, Saku, Chang, Kiyoung, \& Kim, Young Sam. (2016). Does Corporate Board Diversity Affect Corporate Payout Policy?. Asia-Pasifik Journal of Financial Studies, 45(1), 48-101. DOI: $10.1111 /$ ajfs.12119

Custodio, Claudia \& Metzger, Daniel. (2014). Financial expert CEOs: CEO's work experience and firm's financial policies. Journal of Financial Economics, 114(1), 125-154. DOI:10.1016/j.jfineco.2014.06.002

Duong, Dang-Khoa, Phan, Thi Thanh-Phuong, Pho, Kim-Hung, \& McAleer, Michael. (2020). Impact of Board Characteristics and State Ownership on Dividend. Advances in Decision Sciences, 24(4), 1-34. Retrieved from: https://EconPapers.repec.org/RePEc:aag:wpaper:v:24:y:2020:i:4:p:1-34 
Fama, E. \& Jensen M. (1983). Separation of Ownership and Control. Journal of Law and Economics, 26(3), 301-325. DOI: 10.1086/467037

Fauziah, Eldinar Isty \& Probohudono, Agung Nur. (2018). Direksi dan Dewan Komisaris: Pengaruh Dewan Wanita Terhadap Kebijakan Dividen di Indonesia. Jurnal Akuntansi dan Bisnis, 18(1), 61-73. DOI: 10.20961/jab.v18i1.267

Freeman, R. E. (1984). Strategic management: A stakeholder approach. Boston: Pitman Publishing.

Firth, M., Gao, J., Shen, J., \& Zhang, Y. (2016). Institutional stock ownership and firms' cash dividend policies: Evidence from China. Journal of Banking \& Finance, 65(4), 91-107. DOI: 10.1016/j.jbankfin.2016.01.009

Galbreath, Jeremy. (2016). Is board gender diversity linked to financial performance? The mediating mechanism of CSR. Business \& Society, 57(5), 863-889. DOI: 10.1177/0007650316647967

Gujarati Damodar and Dawn Porter. (2015). Dasar-dasar Ekonometrika Buku 2, Edisi 5. Jakarta: Salemba Empat.

Halim, A. (2015). Manajemen Keuangan Bisnis: Konsep dan Aplikasinya. Jakarta: Mitra Wacana Media.

Jensen, M.C., \& Meckling, W.H. (1976). Theory of the Firm: Managerial Behavior, Agency Costs and Ownership Structure. Journal of Financial Economics, 3(4), 305-360. DOI: 10.1016/0304-405X(76)90026-X

Jensen, M.C. (1986). Agency Costs of Free Cash Flow, Corporate Finance, and Takeovers. American Economic Review, 76 (2), 323-329. Retrieved from: https://www.jstor.org/stable/1818789

Mansourinia, E., Emamgholipour, M., Rekabdarkolaei, E.A. \& Hozoori, M. (2013). The effect of board size, board independence and CEO duality on dividend policy of companies. International Journal of Economy, Management and Social Sciences, 2(6), 237-241. Retrieved from: https://www.semanticscholar.org/paper/The-Effect-of-Board-Size\%2CBoard-Independence-and-on-Mansourinia-

Emamgholipour/7a29aa612c3c890972a9b4f9a795750201a9d9ec

Madyoningrum, Asri Winanti. (2019). Pengaruh Firm Size, Leverage, Profitabilitas Terhadap Kebijakan Dividen. Jurnal Bisnis dan Manajemen, 6(1), 45-55. DOI: 10.26905/jbm.v6i1.3034

Nuringsih, Kartika. (2005). Jurnal Akuntansi dan Keuangan Indonesia, 2(2), 103-123. Retrieved from: https://jke.feb.ui.ac.id/index.php/jaki/article/view/2915

Saeed, Abubkr \& Sameer, Muhammad. (2018). Impact of board gender diversity on dividend payments: Evidence from some emerging economies. International Business Review, 26(6), 1100-1113. DOI: 10.1016/j.ibusrev.2017.04.005

Sawicki, Julia. (2009). Corporate governance and dividend policy in Southeast Asia pre- and post-crisis. The European Journal of Finance, 15(2), 211-230. DOI: 10.1080/13518470802604440

Sinabutar, Alexander \& Anggoro Budi Nugroho. (2015). Dividend Payout Ratio In Indonesian Consumer Goods Industry: Panel Analysis And Determinant Factors In 2004-2013. Journal Of Business and Management, 4(4), 453-464. Retrieved from: https://journal.sbm.itb.ac.id/index.php/jbm/article/download/1754/902

Srinidhi, B., Gul, Ferdinand A. \& Tsui, Judi. (2011). Female directors and earnings quality, Contemporary Accounting Research, 28(5), 1610-1644. DOI: 10.1111/j.19113846.2011.01071.x 
Subramaniam, R., Devi, S.S. \& Marimuthu, M. (2011). Investment opportunity set and dividend policy in Malaysia. African Journal of Business Management, 5(24), 10128-10143. DOI: 10.5897/AJBM11.687

Sumail, La Ode. (2018). Corporate Governance and dividend pay-out ratio in non-financial firms listed in Indonesian Stock Exchange. Business and Economics Horizons, 14(4), 851-861. DOI: 10.15208/beh.2018.58

Tahir, Hussain, Masri, Ridzuan, \& Rahman, Mahfuzur. (2020). Determinants of Dividend Pay-Out Policy of Listed Non-financial Firms in Malaysia. International Journal of Financial Research, 11(2), 6876. DOI:10.5430/ijfr.v11n2p68

Thornton, Grant. (2015). Women in business: the path to leadership. Grant Thornton International Business Report. Retrieved https://www.grantthornton.global/globalassets/1.-member-firms/global/insights/ibrcharts/ibr2015_wib_report_final.pdf

Uwalomwa, Uwuigbe, Olamide, Olusanmi, \& Francis, Iyoha. (2015). The Effects of Corporate Governance Mechanisms on Firms Dividend Payout Policy in Nigeria. Journal of Accounting and Auditing: Research \& Practice, 1-11. DOI: 10.5171/2015.313679

Van Pelt, Thomas. (2013). The effect of board characteristics on dividend policy (Thesis). Retrieved from: http://arno.uvt.nl/show.cgi?fid=130666 